\title{
Akibat Kepailitan pada Penegakan Hukum Lingkungan yang Berorientasi Pemulihan oleh Pemerintah dan/atau Pemerintah Daerah
}

\author{
Azam Hawari ${ }^{1}$ dan Deni Daniel ${ }^{2}$
}

\begin{abstract}
Abstrak
Kepailitan bertujuan untuk mengoptimalkan harta debitur guna membayar kepada kreditur-krediturnya. Konsekuensinya, kepailitan menuntun pada eksekusi riil dari instrumen penegakan lingkungan hidup terhadap korporasi--khususnya terhadap harta korporasi-melalui instrumen pidana, perdata, maupun administrasi. Hal ini akan berpengaruh pada pemenuhan pemulihan sebagai sanksi dari penegakan hukum. Lebih jauh lagi, kepailitan menyebabkan pembatasan tagihan dan pengurusan korporasi, sehingga menghambat eksekusi dari instrumen penegakan ini. Oleh karena itu, tulisan ini akan mengeksplorasi hubungan negara dan korporasi yang jatuh pailit dalam berbagai skenario instrumen penegakan dan eksekusi instrumen penegakan. Tulisan ini menemukan bahwa kepailitan membawa implikasi yang beragam pada eksekusi masing-masing instrumen penegakan yang mana perlu dipertimbangkan dalam penegakan hukum lingkungan yang berorientasi pemulihan.
\end{abstract}

Kata kunci: kepailitan, penegakan hukum lingkungan, korporasi

\section{Abstract}

Bankruptcy aims to optimize the debtor's assets in order to pay its creditors. Consequently, bankruptcy leads to the execution of environmental law enforcement instruments on corporations - especially towards corporate assets - via criminal, civil, and administrative instruments. Moreover, this will affect the fulfillment of environmental restoration as the sanction of law enforcement. Furthermore, bankruptcy makes restrictions against bills and corporate management, thus hampering execution of the law enforcement. Therefore, this paper will explore the relationship between a state and a bankrupt corporation in various scenarios of law enforcement. This paper finds that bankruptcy has various consequences on the execution of each law enforcement instrument, which needs to be considered in restorative-oriented-environmental law enforcement.

Keywords: bankruptcy, environmental law enforcement, corporation

\footnotetext{
${ }^{1}$ Penulis adalah analis hukum di bidang lingkungan hidup dan tata guna lahan.

2 Penulis merupakan asisten pengacara di firma hukum ArpanLaw.
} 


\section{Pendahuluan}

Prinsip 2 Rio Declaration on Environment Development mengatur asas tanggung jawab negara yang mewajibkan negara untuk mencegah pencemaran dan/ atau kerusakan lingkungan hidup. ${ }^{3}$ Asas ini juga diadopsi dalam Undang-Undang No. 32 Tahun 2009 tentang Perlindungan dan Pengelolaan Lingkungan Hidup (UU PPLH). ${ }^{4}$ Salah satu perwujudan asas ini dilakukan melalui penegakan hukum lingkungan.

Penegakan hukum lingkungan tidak hanya ditujukan untuk menghukum perusak atau pencemar, melainkan juga memulihkan lingkungan hidup. ${ }^{5}$ UU PPLH mengatur tiga jenis instrumen penegakan hukum, yakni administrasi, pidana, dan perdata. Secara umum, ketiga instrumen tersebut memiliki berbagai karakteristik yang berbeda dalam penggunaannya. Ketiga instrumen ini dapat diterapkan kepada pelaku pelanggaran korporasi secara bersamaan sepanjang sesuai dengan tujuan yang hendak dicapai. $^{6}$

Korporasi yang tidak dapat memenuhi kewajiban bayar, termasuk pembayaran sanksi dalam kepailitan berpotensi menghadapi kepailitan. Kepailitan merupakan suatu keadaan di mana debitur tidak mampu untuk melakukan pembayaran-pembayaran terhadap utang-utang dari para krediturnya. ${ }^{7}$ Tujuan kepailitan adalah untuk menghindari sitaan terpisah dan eksekusi terpisah oleh kreditir sehingga seluruh kekayaan debitur disita secara bersama agar menjamin seluruh kreditur mendapat hak-haknya. ${ }^{8}$ Dengan "beku"-nya aset korporasi yang pailit, maka eksekusi sanksi penegakan hukum lingkungan memiliki tantangan yang berdampak pada pemenuhan tujuan pemulihan lingkungan hidup.

Saat ini belum terdapat literatur yang membahas akibat kepailitan terhadap pe-

\footnotetext{
${ }^{3}$ United Nations General Assembly, Report of the United Nations Conference on Environment and Development, Rio de Janeiro, 3-14 Juni 1992, Annex I Principle 2, yang menyatakan:

${ }^{4}$ Indonesia (1), Undang-Undang Perlindungan dan Pengelolaan Lingkungan Hidup, UU No. 32 Tahun 2009, LN No. 140 Tahun 2009, TLN No. 5059, Pasal 2 huruf a.

${ }^{5}$ Zairin Harahap, "Penegakan Hukum Lingkungan Menurut Hukum Lingkungan", Jurnal Hukum, Vol. 11, No. 27, (September 2004), hlm. 8.

${ }^{6}$ Penegakan hukum lingkungan melalui pelbagai instrumen terhadap satu korporasi yang sama untuk mencapai tujuan yang berbeda Pengadilan Tata Usaha Negara Jakarta, Putusan No. 104/G/ LH/2017/PTUN-JKT, hlm. 5; Pengadilan Negeri Tanjung Jabung Timur, Putusan Nomor 40/Pid.SusLH/2019/PN Tjt, hlm. 103; Pengadilan Tinggi DKI Jakarta, Putusan Nomor 296 /PDT/2020/PT.DKI, hlm. 171.

${ }^{7}$ M. Hadi Shubhan, Hukum Kepailitan: Prinsip, Norma, dan Praktik di Peradilan, (Jakarta: Kencana, 2009), hlm. 1.

${ }^{8}$ Imran Nating, Peranan Dan Tanggung Jawab Kurator Dalam Pengurusan Dan Pemberesan Kepailitan, (Jakarta: Raja Grafindo Persada, 2005), hlm. 9.
} 
negakan hukum lingkungan, khususnya yang dilakukan oleh Pemerintah. ${ }^{9}$ Tulisan ini akan membahas dampak hukum yang ditimbulkan dari kepailitan terhadap efektivitas implementasi penegakan hukum lingkungan oleh Pemerintah, khususnya terhadap pemenuhan tujuan pemulihan lingkungan.

\section{Selayang Pandang Hukum Kepaili- tan di Indonesia}

\section{A. Kepailitan dan Akibat Hukumnya}

Kepailitan didefinisikan sebagai "sita umum atas semua kekayaan Debitor Pailit yang pengurusan dan pemberesannya dilakukan oleh kurator di bawah pengawasan hakim pengawas sebagaimana diatur dalam Undang-Undang ini."10 Suatu korporasi hanya dapat dipailitkan melalui putusan pengadilan niaga yang dimohonkan olehnya, atau oleh krediturnya. ${ }^{11}$ Syarat dikabulkannya suatu permohonan pailit adalah:

1. debitur terbukti mempunyai 2 (dua) atau lebih kreditur;12

2. debitur tidak membayar lunas se- dikitnya 1 (satu) utang yang telah jatuh waktu dan dapat ditagih;, ${ }^{13}$

3. syarat 1) dan 2) terbukti secara sederhana. ${ }^{14}$

Terdapat 5 syarat kualifikasi perikatan sebagai utang dalam Undang-undang No. 37 Tahun 2004 tentang Kepailitan dan Penundaan Kewajiban Pembayaran Utang (UU KPKPU). Pertama, perikatan tersebut adalah kewajiban yang dirumuskan atau dapat dirumuskan dalam nominal uang. Kedua, perikatan tersebut adalah perikatan yang sudah terjadi atau yang akan timbul di masa depan. Ketiga, perikatan tersebut lahir berdasarkan perjanjian atau berdasarkan undang-undang. Keempat, perikatan tersebut merupakan perikatan yang wajib dilaksanakan oleh debitur. Kelima, jika perikatan tidak dipenuhi, kreditur dapat memperoleh pemenuhan dari harta milik debitur. ${ }^{15}$

Setelah putusan pernyataan pailit diucapkan, debitur akan kehilangan haknya untuk menguasai dan mengurus kekayaannya yang termasuk dalam

${ }^{9}$ Untuk selanjutnya, istilah "Pemerintah" merujuk pada Pemerintah Pusat yakni Kementerian Lingkungan Hidup dan Kehutanan dan juga Pemerintah Daerah.

${ }^{10}$ Indonesia (2), Undang-undang Kepailitan dan Penundaan Kewajiban Pembayaran Utang, UU No. 37 Tahun 2004, LN No. 131 Tahun 2004, TLN No. 4443, Pasal 1 angka 1.

${ }^{11}$ Ibid., Pasal 2 ayat (1).

12 Ibid., Pasal 2 ayat (1).

${ }^{13}$ Ibid., Pasal 2 ayat (1).

${ }^{14}$ Ibid., Pasal 8 ayat (4).

${ }^{15}$ Ibid., Pasal 1 angka 6. 
harta pailit. ${ }^{16}$ Harta pailit adalah harta kekayaan debitur beserta apa yang debitur dapatkan selama debitur dalam keadaan pailit. ${ }^{17}$ Sebagai suatu sita umum, kepailitan bermaksud untuk menghentikan aksi terhadap perebutan harta pailit oleh para kreditur dan menghentikan lalu lintas transaksi terhadap harta pailit oleh debitur yang dapat merugikan para kreditur. ${ }^{18}$ Selain itu, sita umum juga mengangkat seluruh sita terhadap harta pailit. ${ }^{19}$ Oleh karena debitur pailit kehilangan hak untuk menguasai dan mengurus hartanya, maka seluruh perikatannya yang terjadi setelah pailit tidak lagi dibayar dari harta pailit kecuali jika perikatan tersebut menguntungkan harta pailit. ${ }^{20}$ Setelah berlakunya kepailitan, pihak yang berwenang untuk mengurus dan/atau membereskan harta pailit adalah kurator. ${ }^{21}$ Kurator menjadi pihak yang mempunyai legal standing in judicio atas harta pailit.

UU KPKPU menentukan tiga akibat hukum terhadap perkara debitur yang sedang berlangsung atau dengan kata lain belum berkekuatan hukum tetap. Pertama, untuk tuntutan hukum yang diajukan debitur, maka perkara tersebut dapat diambil alih oleh kurator namun bila tidak maka segala putusan akan berada di luar tanggungan harta pailit. ${ }^{22}$ Kedua, untuk tuntutan hukum yang diajukan terhadap debitur - sepanjang bertujuan untuk memperoleh kewajiban dari harta pailit-akan gugur demi hukum. ${ }^{23}$ Dengan demikian, penggugat yang perkaranya digugurkan harus mengajukan tagihannya, untuk dicocokkan dalam rapat pencocokan piutang bersama dengan para kreditur lain. ${ }^{24}$ Ketiga, kepailitan juga mengakhiri segala bentuk pelaksanaan atau eksekusi putusan pengadilan terhadap kekayaan debitur yang sedang berjalan. ${ }^{25}$ Seluruh penghentian perkara tersebut bertujuan untuk menghindari dan menghentikan perebutan harta yang saling mendahului dan saling adu kekuatan. Hal ini dilakukan demi perlindungan kreditur dengan kekuatan yang timpang terhadap harta debitur. ${ }^{26}$

\footnotetext{
${ }^{16}$ Ibid., Pasal 24 ayat (1).

17 Ibid., Pasal 1 angka 1 dan Pasal 21; Shubhan, Op. cit., hlm. 163.

${ }^{18}$ Shubhan, Op.Cit., hlm. 164.

${ }^{19}$ Indonesia (2), Op.Cit., Pasal 31 ayat (2).

${ }^{20}$ Ibid., Pasal 25.

${ }^{21}$ Indonesia (2), Op.Cit., Pasal 16 ayat (1).

${ }^{22}$ Ibid., Pasal 28.

${ }^{23}$ Ibid., Pasal 29.

${ }^{24}$ Ibid., Pasal 27; Sutan Remy Sjahdeini, Hukum Kepailitan: Memahami Undang-undang No. 37 Tahun 2004 tentang Kepailitan, (Jakarta: Pustaka Utama Grafiti, 2009), hlm. 201.

${ }^{25}$ Ibid., Pasal 31 ayat (1).

${ }^{26}$ Shubhan, Op.Cit., hlm. 168-169.
} 
Akibat Kepailitan pada Penegakan Hukum Lingkungan yang Berorientasi Pemulihan oleh Pemerintah dan/atau Pemerintah Daerah

Meski demikian, UU KPKPU tetap mempertahankan hak eksekusi dari kreditur pemegang gadai, jaminan fidusia, hak tanggungan, hipotek, atau hak agunan atau kebendaan lainnya (kreditur separatis) seolah-olah tidak terjadi kepailitan. ${ }^{27}$ Dengan kata lain, harta pailit yang menjadi jaminan tidak diberlakukan sita umum.

Kepailitan juga membuka peluang bagi kreditur untuk mengajukan permohonan pembatalan kepada perbuatan debitur terhadap harta kekayaannya sebelum ia jatuh pailit, yang dikenal dengan actio pauliana. ${ }^{28}$ Syarat agar permohonan pembatalan dilakukan adalah jika terbukti bahwa debitur dan pihak terkait mengetahui atau sepatutnya mengetahui bahwa perbuatan hukum tersebut akan mengakibatkan kerugian bagi kreditur sewaktu dilakukan. ${ }^{29}$ Namun, UU KPKPU mengecualikan actio pauliana jika perbuatan hukum tersebut diwajibkan oleh perjanjian dan/atau undang-undang. ${ }^{30}$

\section{B. Pengurusan dan Pemberesan Harta Pailit setelah Pailitnya Debitur}

Pasca putusan pailit, debitur akan memasuki tahap pengurusan. Sebagai akibat putusan pailit, direksi dari korporasi akan kehilangan kekuasaan untuk mengelola korporasinya dan menjadi "terpasung". Segala keputusan diambil dan dilaksanakan oleh kurator dan direksi atau pengurus akan tunduk pada perintah dari kurator. ${ }^{31}$ Terdapat beberapa hal yang dapat terjadi selama tahap pengurusan.

Pertama, kurator dapat melanjutkan usaha korporasi pailit dengan izin dari hakim pengawas. ${ }^{32}$ UU KPKPU "mengambil suatu sikap" untuk mempertahankan nilai harta pailit sehingga tidak mengalami kemunduran, dan bahkan bertambah. ${ }^{33}$ Kepailitan membatasi kewenangan kurator untuk melakukan penjualan benda dalam harta pailit yang tidak diperlukan untuk kelangsungan usaha. ${ }^{34}$

Kedua, kurator akan melakukan pencocokan piutang dengan pembentukan daftar utang dan piutang debitur pailit yang dilakukan sebelum pembayaran

\footnotetext{
${ }^{27}$ Indonesia (2), Op.Cit., Ps. 55 ayat (1).

${ }^{28}$ Ibid., Pasal 41 ayat (1).

${ }^{29}$ Ibid., Pasal 41 ayat (2).

${ }^{30}$ Ibid., Pasal 41 ayat (3).

${ }^{31}$ Sjahdeini, Op.Cit., hlm. 191.

32 Indonesia (2), Op.Cit., Pasal 104.

33 Sjahdeini, Op.Cit., hlm. 224.

${ }^{34}$ Indonesia (2), Op.Cit., Pasal 184 ayat (2) dan Sjahdeini, Op.Cit., hlm. 224
} 
piutang dari masing-masing kreditur. ${ }^{35}$ Piutang-piutang yang disetujui kurator akan dimasukkan dalam suatu daftar piutang yang sementara diakui, dan piutang yang dibantah dimasukkan dalam daftar tersendiri, termasuk alasannya. ${ }^{36}$

Ketiga, debitur pailit dapat menawarkan rencana perdamaian kepada kreditur-kreditur. ${ }^{37}$ Kreditur yang berhak mengeluarkan suara terhadap rencana perdamaian dalam kepailitan hanyalah kreditur konkuren. Rencana perdamaian tersebut dapat disahkan oleh Pengadilan Niaga dan berlaku bagi seluruh kreditur konkuren. ${ }^{38}$ Pengesahan perdamaian yang telah berkekuatan hukum tetap akan mengakhiri kepailitan. ${ }^{39}$ Jika debitur lalai memenuhi isi perdamaian tersebut, maka kreditur dapat menuntut pembatalannya yang jika dikabulkan akan membuka kembali kepailitan dan dilanjutkan dengan pemberesan harta pailit. $^{40}$

Pemberesan dimulai saat harta debitur pailit dalam keadaan insolvensi atau jika perdamaian dibatalkan. ${ }^{41}$ Selama pemberesan, usaha debitur pailit dapat dilanjutkan jika diusulkan oleh kreditur atau kreditur yang hadir, dan disetujui oleh kreditur konkuren dan kreditur dengan hak didahulukan. ${ }^{42}$ Di sisi lain, usaha debitur yang tadinya dilanjutkan oleh kurator dapat dihentikan atas perintah hakim pengawas jika diminta oleh kreditur atau kurator. ${ }^{43}$

Dalam tahap pemberesan, kurator akan menjual harta pailit. ${ }^{44}$ Harta pailit selanjutnya akan dibagi sesuai daftar pembagian yang disusun kurator dan disetujui hakim pengawas. ${ }^{45}$ Tahap kepailitan berakhir jika kreditur yang tagihannya diterima memperoleh jumlah

\footnotetext{
${ }^{35}$ Indonesia (2), Op.Cit., Pasal 100.

${ }^{36}$ Ibid., Pasal 117.

${ }^{37}$ Ibid., Pasal 144.

${ }^{38}$ Ibid., Pasal 159 dan Pasal 162.

${ }^{39}$ Ibid., Pasal 166 ayat (1).

${ }^{40}$ Ibid., Pasal 170 ayat (1), 172 ayat (1), 175 ayat (2).

${ }^{41} \mathrm{Ibid}$., Pasal 178 ayat (2). Keadaan insolvensi terjadi jika: (i) dalam rapat pencocokan piutang tidak ditawarkan rencana perdamaian; (ii) rencana perdamaian yang ditawarkan tidak diterima; (iii) pengesahan perdamaian ditolak berdasarkan putusan yang telah memperoleh kekuatan hukum tetap

${ }^{42}$ Ibid., Pasal 179 ayat (1) dan Pasal 180 ayat (1), Pasal 181 ayat (1).

${ }^{43}$ Ibid., Pasal 183 ayat (1).

${ }^{44}$ Ibid., Pasal 184 ayat (1)

${ }^{45}$ Ibid., Pasal 189 ayat (1). Daftar pembagian tersebut memuat rincian: (i) penerimaan dan pengeluaran, termasuk upah Kurator; (ii) nama kreditur; (iii) jumlah yang dicocokkan dari tiap piutang; (iv) bagian yang wajib diberikan kepada kreditur.
} 
Akibat Kepailitan pada Penegakan Hukum Lingkungan yang Berorientasi Pemulihan oleh Pemerintah dan/atau Pemerintah Daerah

penuh piutang mereka atau jika daftar pembagian penutup menjadi mengikat. ${ }^{46}$ Usai tahap pemberesan, korporasi yang berbentuk perseroan terbatas akan dibubarkan dan dilikuidasi. ${ }^{47}$

\section{Penegakan Hukum Lingkungan terhadap Korporasi}

Penegakan hukum lingkungan merupakan upaya untuk mencapai ketaatan terhadap peraturan perundang-undangan yang berlaku di bidang lingkungan hidup, yang terdiri dari instrumen administrasi, pidana, dan keperdataan. ${ }^{48} \mathrm{Ke}-$ tiga lingkup penegakan hukum ini telah diatur dalam UU PPLH.

\section{A. Penegakan Hukum Perdata oleh Pe- merintah}

Penegakan hukum perdata oleh Pemerintah dilakukan melalui hak gugat di pengadilan atau penyelesaian sengketa di luar pengadilan. ${ }^{49}$ Penegakan hukum melalui pengadilan tersebut dapat dilakukan melalui gugatan perbuatan melawan hukum ${ }^{50}$ atau gugatan tanggung jawab mutlak ${ }^{51}$ di pengadilan negeri atas tindakan korporasi. ${ }^{52}$ UU PPLH menentukan dua jenis tuntutan yang dapat dimohonkan dalam hak gugat Pemerintah, yaitu "ganti kerugian" dan "tindakan tertentu". ${ }^{53}$ Ganti kerugian lingkungan hidup terdiri dari beberapa jenis, salah satunya adalah kerugian untuk pengganti biaya penanggulangan pencemaran dan/atau kerusakan lingkungan hidup serta pemulihan lingkungan hidup; dan/atau kerugian ekosistem. ${ }^{54}$ Baik ganti kerugian maupun biaya pemulihan-yang diajukan oleh Pemerintah Pusat maupun Pemerintah Daerah-akan menjadi pendapatan negara bukan pajak dan akan disetorkan ke kas negara. ${ }^{55}$ Sedangkan, tindakan tertentu dapat beru-

${ }^{46}$ Ibid., Pasal 202 ayat (1).

${ }^{47}$ Ibid., Pasal 142 ayat (1) huruf e.

${ }^{48}$ Laode M Syarif dan Andri G Wibisana, ed., Hukum Lingkungan Teori, Legislasi, dan Studi Kasus, s.1. (USAID-Kemitraan Partnership-the Asia Foundation, 2015), hlm. 495.

${ }^{49}$ Indonesia (1), Op. cit., Pasal 85 ayat (1) dan Pasal 90 ayat (1).

${ }^{50}$ Munir Fuady, Perbuatan Melawan Hukum Pendekatan Kontemporer, (Jakarta: PT Citra Aditya Bakti, 2005).

51 Andri Gunawan Wibisana (1), “Tangan Tuhan di Pengadilan: Dalih Bencana Alam dan Pertanggungjawaban Perdata dalam Kasus Lingkungan" Jurnal Hukum dan Pembangunan, Vol. 41, No. 1, (Januari-Maret 2011).

52 Indonesia (1), Op.Cit., Pasal 87 ayat (1) dan Pasal 88.

${ }^{53}$ Ibid., Pasal 90 ayat (1).

54 Pengadilan Tinggi Jambi, Putusan No. 65/PDT-LH/2017/PT JMB, hlm 89-90; Indonesia (3), Menteri Lingkungan Hidup, Peraturan Menteri tentang Kerugian Lingkungan Hidup Akibat Pencemaran dan/atau Kerusakan Lingkungan Hidup, Permen No. 7 Tahun 2014, BN No. 1726 Tahun 2014, Pasal 3.

55 Ibid., Pasal 80; Indonesia (4), Peraturan Pemerintah tentang Jenis dan Tarif atas Jenis Penerimaan Negara Bukan Pajak yang Berlaku pada Kementerian Lingkungan Hidup, PP No. 44 Tahun 2014, LN No. 124 Tahun 2014, TLN No. 5540, Pasal 1 ayat (1) huruf k angka 1; 
pa perintah untuk memulihkan kerugian lingkungan.

Penegakan hukum perdata di luar pengadilan oleh Pemerintah dituangkan melalui kesepakatan para pihak. ${ }^{56} \mathrm{Ke}-$ sepakatan tersebut setidaknya memuat kewajiban pencemar untuk melakukan tindakan tertentu berupa perbaikan pengelolaan lingkungan hidup dan penghentian pelanggaran; atau membayar kerugian lingkungan hidup. ${ }^{57}$

Pembayaran dari penegakan hukum perdata di luar pengadilan-baik yang dilakukan oleh Pemerintah Pusat maupun Pemerintah Daerah - akan menjadi Pendapatan Negara Bukan Pajak (PNBP) dan disetorkan ke kas negara. ${ }^{58}$ Putusan-putusan yang menghukum korporasi maupun kesepakatan penyelesaian sengketa lingkungan hidup di luar pengadilan menimbulkan hubungan hukum kreditur-debitur antara Pemerintah dengan korporasi. Namun, hanya ganti kerugian lingkungan hidup yang memenuhi syarat sebagai utang sehingga mempunyai akibat dalam kepailitan. ${ }^{59}$ Petitum hukuman membayar biaya pemulihan, hukuman memulihkan kerugian lingkungan hidup, dan kesepakatan membayar kerugian lingkungan hidup merupakan manifestasi pemenuhan tujuan pemulihan dalam penegakan hukum perdata. ${ }^{60}$

Berdasarkan penjelasan tersebut sanksi dari penegakan hukum perdata yang terimbas kepailitan adalah hukuman ganti kerugian dan biaya pemulihan. Eksekusi dari hukuman tersebut akan dilakukan melalui proses dalam hukum kepailitan, yakni pendaftaran tagihan kepada kurator.

\section{B. Penegakan Hukum Pidana terhadap Korporasi}

Penegakan hukum pidana, termasuk bagi korporasi, bertumpu pada penjatuhan sanksi pidana bagi pelanggar hukum melalui putusan pengadilan. ${ }^{61}$ Untuk dapat dihukum, subjek hukum pribadi kodrati ataupun badan hukum harus mempunyai kesalahan. ${ }^{62}$ Unsur

\footnotetext{
${ }^{56}$ Indonesia (3), Op.Cit., Pasal 7 ayat (2).

${ }^{57}$ Ibid., Lampiran III, Pasal 1.

${ }^{58}$ Indonesia (3), Op.Cit, Pasal 8; Indonesia (4), Op. cit., Ps. 1 ayat (1) huruf k angka 2.

${ }^{59}$ Indonesia (2), Op.Cit., Pasal 1 angka 6.

${ }^{60}$ Meski demikian, tidak ada ketentuan yang mewajibkan agar biaya pemulihan yang dibayarkan secara khusus diperuntukkan pada pemulihan lingkungan. Hal ini disebabkan pembayaran dilakukan ke kas negara. Menurut Penulis, Pemerintah dapat menyinkronkan penegakan hukum perdata dengan Dana Penanggulangan Pencemaran dan/atau Kerusakan dan Pemulihan Lingkungan Hidup. Indonesia (1), Op. cit., Pasal 43 ayat (2).

${ }^{61}$ C.S.T. Kansil dan Christine S.T. Kansil, Pokok-pokok Hukum Pidana, (Jakarta: Pradnya Paramita, 2004), hlm. 54.

${ }^{62}$ R. Soesilo, Pokok-Pokok Hukum Pidana Peraturan Umum dan Delik-Delik Khusus, Cetakan ke-1, (Sukabumi: PT. Karya Nusantara,1984), hlm. 28.
} 
Akibat Kepailitan pada Penegakan Hukum Lingkungan yang Berorientasi Pemulihan oleh Pemerintah dan/atau Pemerintah Daerah

kesalahan ini, dapat berupa kesengajaan ataupun kelalaian.

Hukum pidana dapat diambil sebagai jalan terakhir ketika sanksi lain tidak efektif. Dalam konteks pidana lingkungan, UU PPLH mengatur bahwa penegakan hukum pidana sebagai ultimum remedium ini bersifat terbatas. Penerapan asas ini hanya diberlakukan bagi tindak pidana formil tertentu, yaitu pemidanaan terhadap pelanggaran baku mutu air limbah, emisi, dan gangguan. ${ }^{63}$

UU PPLH mengatur bahwa pidana pokok dalam kejahatan lingkungan adalah penjara dan denda. ${ }^{64}$ Sedangkan untuk pidana yang dilakukan oleh korporasi, dapat dikenakan pidana tambahan atau tindakan tata tertib, berupa: (i) perampasan keuntungan yang diperoleh dari tindak pidana; (ii) penutupan seluruh atau sebagian tempat usaha dan/ atau kegiatan; (iii) perbaikan akibat tindak pidana; (iv) kewajiban mengerjakan apa yang dilalaikan tanpa hak; (v) penempatan perusahaan/korporasi di bawah pengampuan paling lama tiga tahun. ${ }^{65}$

Tujuan pemulihan lingkungan hidup dalam penegakan hukum pidana dapat dicapai melalui pidana tambahan perbaikan akibat tindak pidana. Dalam penerapannya, pidana tambahan perbaikan akibat tindak pidana merupakan hukuman yang dijatuhkan kepada korporasi dalam bentuk kewajiban melakukan tindakan. ${ }^{66}$

Pidana pokok denda dan pidana tambahan perampasan keuntungan yang diperoleh dari tindak pidana merupakan jenis sanksi yang berkaitan langsung dengan harta kekayaan korporasi. Denda yang dibayar akan dimasukkan sebagai PNBP. ${ }^{67}$ Sementara itu, kekayaan korporasi sebagai hasil tindak pidana yang dirampas--atau hasil lelang jika berbentuk barang-juga akan dimasukkan sebagai PNBP. ${ }^{68}$ Kedua sanksi yang berkaitan dengan harta kekayaan korporasi akan terdampak dengan adanya kepailitan. Sebagaimana dibahas di atas, kepailitan

${ }^{63}$ Indonesia, UU PPLH, (1), Op.Cit., Penjelasan Umum.

${ }^{64}$ Ibid., Bab XV.

${ }^{65}$ Ibid., Pasal 119.

${ }^{66}$ Misalnya dalam Perkara Adei Plantation yang berkekuatan hukum tetap pada Putusan 2042 K/ Pdt.Sus/2015 menghukum debitur untuk melakukan "perbaikan-perbaikan akibat tindak pidana untuk memulihkan lahan yang rusak akibat kebakaran lahan seluas 40 ha melalui pemberian kompos, dengan biaya sebesar Rp15.141.826.779,325." Amar putusan tersebut memberikan kewajiban kepada korporasi untuk melakukan tindakan pemulihan dan bukan sekadar membayar biaya pemulihan.

${ }^{67}$ Indonesia, Pemerintah Indonesia, (6), Peraturan Pemerintah tentang Jenis dan Tarif Atas Jenis Penerimaan Negara Bukan Pajak Yang Berlaku Pada Kejaksaan Republik Indonesia, PP No. 39 Tahun 2016, LN No. 199 Tahun 2016, TLN No. 5935, Pas.al 1 ayat (1) huruf c.

${ }^{68} \mathrm{Ibid}$., Ps. 1 ayat (1) huruf $\mathrm{f}$ dan i. 
merupakan sita umum terhadap harta korporasi yang jatuh pailit sehingga menghilangkan hak penguasaan dan pengurusan korporasi pailit terhadap harta pailit. Dengan begitu, eksekusi sanksi tersebut akan dilakukan terhadap harta pailit yang dipisahkan dari harta kekayaan korporasi.

\section{Penegakan Hukum Administrasi terhadap Korporasi oleh Pemerintah}

Sanksi administrasi dianggap sebagai sarana hukum publik berupa penjatuhan beban oleh pemerintah terhadap masyarakat dan pelaku usaha untuk merespons ketidaktaatan pemenuhan kewajiban yang muncul dari peraturan perundang-undangan. ${ }^{69}$ Sebagai salah satu kewenangan pemerintah, sanksi administrasi dikenakan secara langsung tanpa melalui prosedur peradilan dan bila perlu dengan paksaan fisik untuk menyesuaikan situasi faktual dengan norma-norma yang ada. ${ }^{70}$ Sanksi administrasi tersebut berupa: (i) teguran tertulis; (ii) paksaan pemerintah; (iii) pembekuan izin lingkungan; (iv) pencabutan izin lingkungan; (v) denda atas keterlam- batan pelaksanaan paksaan pemerintah (denda keterlambatan). ${ }^{71}$ Paksaan pemerintah memenuhi tujuan pemulihan lingkungan hidup karena dapat membebankan kewajiban pada korporasi untuk melakukan tindakan memulihkan fungsi lingkungan hidup. ${ }^{72}$ Selain itu, denda keterlambatan juga memiliki fungsi pemulihan karena mendorong pelanggar/penerima sanksi memperbaiki keadaan dan menghentikan pelanggarannya. ${ }^{73}$ Meskipun demikian, UU PPLH dan Peraturan Menteri Lingkungan Hidup No. 2 Tahun 2013 tentang Pedoman Penerapan Sanksi Administratif di Bidang Perlindungan dan Pengelolaan Lingkungan Hidup (Permen LH No. 2 Tahun 2013) mengatur bahwa sanksi paksaan pemerintah ini hanya merupakan perintah kepada korporasi untuk melakukan paksaan dan bukan tindakan nyata oleh Pemerintah terhadap korporasi. ${ }^{74}$

Permen LH No. 2 Tahun 2013 mengubah nomenklatur denda keterlambatan dalam UU PPLH menjadi denda administratif. ${ }^{75}$ Penggunaan frasa denda administratif ini menuai kritik karena

${ }^{69}$ Andri Gunawan Wibisana, (2), “Tentang Ekor yang Tak Lagi Beracun: Kritik Konseptual atas Sanksi Administratif dalam Hukum Lingkungan di Indonesia", Jurnal Hukum Lingkungan Indonesia, Vol. 6, No. 1, (Oktober, 2019), hlm. 49.

${ }^{70}$ Laode M Syarif dan Andri G Wibisana, Hukum Lingkungan, Op.Cit., hlm. 496.

${ }^{71}$ Ibid., Pasal 76 ayat (2).

${ }^{72}$ Ibid., Pasal 80 ayat (1) huruf g.

${ }^{73}$ Wibisana (2), Op.Cit, hlm. 65.

${ }^{74}$ Ibid, hlm. 68.

${ }^{75}$ Indonesia (7), Menteri Lingkungan Hidup, Peraturan Menteri Lingkungan Hidup Pedoman Penerapan Sanksi Administratif di Bidang Perlindungan dan Pengelolaan Lingkungan Hidup, Permen LH No. 2 
Akibat Kepailitan pada Penegakan Hukum Lingkungan yang Berorientasi Pemulihan oleh Pemerintah dan/atau Pemerintah Daerah

secara konseptual mempunyai makna yang berbeda dengan denda keterlambatan. ${ }^{76}$ Pengenaan denda keterlambatan terhitung mulai sejak jangka waktu pelaksanaan paksaan pemerintah tidak dilaksanakan. ${ }^{77}$ Uang yang diperoleh dari denda keterlambatan yang dikenakan oleh Menteri di bidang lingkungan hidup akan menjadi kas negara sebagai bagian dari PNBP. ${ }^{78}$ Selain itu, Peraturan Pemerintah No. 12 Tahun 2019 tentang Pengelolaan Keuangan Daerah tidak menyertakan denda keterlambatan yang dikenakan oleh Kepala Daerah sebagai Pendapatan Asli Daerah. ${ }^{79}$ Pelaksanaan pembayaran denda keterlambatan yang dikenakan Kepala Daerah bervariasi. Ada peraturan daerah yang secara spesifik menentukan agar denda keterlambatan disetor ke kas daerah, ${ }^{80}$ ada juga peraturan daerah yang tidak mengatur. ${ }^{81}$

Berdasarkan penjelasan di atas, denda keterlambatan menjadi sanksi admi- nistrasi yang berpotensi terdampak oleh kepailitan. Denda keterlambatan akan menjadi utang yang perlu didaftarkan oleh Pemerintah kepada kurator.

\section{Akibat Hukum Kepailitan terhadap Penegakan Hukum Lingkungan Yang Berorientasi pada Pemulihan}

\section{A. Terhadap Penegakan Hukum Lingkungan Perdata}

\section{Terhadap Penegakan Hukum Ling- kungan Perdata melalui Pengadilan}

Penegakan hukum lingkungan perdata tunduk pada Pasal 29 UU KPKPU yang menggugurkan tuntutan hukum di pengadilan yang bertujuan untuk memperoleh pemenuhan kewajiban dari harta pailit. $^{82}$ Artinya, penegakan hukum lingkungan perdata akan gugur apabila belum berkekuatan hukum tetap. Dengan demikian, kapan suatu putusan penegakan hukum lingkungan perdata berkekuatan hukum tetap akan menen-

Tahun 2013, BN No. 314 Tahun 2013, Lampiran I, hlm. 5, yang menyatakan: “Denda administratif adalah pembebanan kewajiban untuk melakukan pembayaran sejumlah uang tertentu kepada penanggung jawab usaha dan/atau kegiatan karena terlambat untuk melakukan paksaan pemerintahan."

${ }^{76}$ Wibisana (2), Op.Cit., hlm. 50.

${ }^{77}$ Ibid., Pasal 6.

${ }^{78}$ Indonesia (4), Op.Cit., Pasal 1 ayat (1) huruf 1.

${ }^{79}$ Indonesia (8), Pemerintah Indonesia, Peraturan Pemerintah tentang Pengelolaan Keuangan Daerah, PP No. 12 Tahun 2019, LN No. 42 Tahun 2019, TLN No. 6322, Pasal 31.

${ }^{80}$ Indonesia (9), Bupati Bangka Barat, Peraturan Bupati tentang Pedoman Penerapan Sanksi Administratif di Bidang Perlindungan dan Pengelolaan Lingkungan Hidup, Perbup No. 15 Tahun 2015, BD No. 2 Tahun 2015, Pasal 11 ayat (3) mengatur agar "Pembayaran denda oleh penanggung jawab usaha dan/atau kegiatan dilakukan secara tunai melalui kas daerah Kabupaten Bangka Barat."

${ }^{81}$ Indonesia (10), Gubernur Sumatera Selatan, Peraturan Gubernur tentang Tata Cara Penerapan Sanksi Administratif di Bidang Perlindungan dan Pengelolaan Lingkungan Hidup, Pergub No. 12 Tahun 2019, BD No. 12 Tahun 2019, Pasal 6.

${ }^{82}$ Indonesia (2), Op.Cit., Pasal 29. 
tukan kedudukan Pemerintah dalam proses kepailitan.

Apabila korporasi telah dinyatakan pailit sebelum putusan pengadilan perdata berkekuatan hukum tetap, maka gugatan tersebut akan gugur demi hukum. ${ }^{83}$ Dalam gugatan ganti rugi atas kerusakan dan/atau pencemaran lingkungan hidup, Pemerintah dapat mengajukan ganti rugi atau biaya pemulihan terhadap harta pailit. Dalam praktiknya, hakim akan memutuskan bahwa perkara di mana debitur telah dinyatakan pailit maka gugatan gugur demi hukum terlepas dari seberapa jauh persidangan tersebut telah berjalan. Dalam Putusan Pengadilan Negeri Malang No. 139/Pdt.G/2013/PN Mlg, Majelis Hakim mempertimbangkan bahwa karena debitur dinyatakan pailit tanggal 30 Juli 2013 maka gugatan yang diajukan pada tanggal 26 Juni 2013 gugur demi hukum. ${ }^{84}$ Bahkan, perkara yang telah diputus pada pengadilan tingkat pertama dan sedang diajukan upaya hukum juga akan gugur. Dalam Putusan Mahkamah Agung (MA) No. 345 K/PDT/2009, MA pada tingkat kasasi menggugurkan perkara yang sudah diputus hingga tahap banding pada tanggal 19 Juni 2008 karena debitur di- nyatakan pailit pada tanggal 3 September 2008 melalui Putusan Pengadilan Niaga pada Pengadilan Negeri Jakarta Pusat No. 42/Pailit/2008/PN.Niaga JKT.Pst., ${ }^{85}$

Kedua, jika korporasi dinyatakan pailit setelah putusan pengadilan perdata berkekuatan hukum tetap. Jika putusan penegakan hukum lingkungan perdata telah masuk tahap eksekusi, maka eksekusinya akan berhenti setelah diucapkannya putusan pernyataan pailit. ${ }^{86}$ Namun apabila terdapat eksekusi pengadilan berupa penjualan benda bergerak dan/atau tidak bergerak yang sudah ditetapkan sebelumnya, maka kurator dapat melanjutkan penjualan itu dengan izin hakim pengawas. ${ }^{87}$ Dengan berhentinya proses eksekusi, satu-satunya langkah agar sanksi pengadilan perdata dapat dibayar adalah dengan didaftarkan kepada kurator sebagai tagihan untuk dicocokkan. ${ }^{88}$ Dengan didaftarkan kepada kurator sebagai tagihan, eksekusi ini akan tunduk pada ketentuan kepailitan. Eksekusi setelah didaftarkan ini akan dipengaruhi oleh posisi pemerintah sebagai kreditur. Hal ini akan dipaparkan lebih dalam pada Bab IV-D.

Tujuan pemulihan melalui penegakan hukum perdata di pengadilan yang

\footnotetext{
${ }^{83}$ Ibid.

${ }^{84}$ Pengadilan Negeri Malang, Putusan Nomor 139/Pdt.G/2013/PN.Mlg, hlm. 21.

${ }^{85}$ Mahkamah Agung Republik Indonesia, Putusan No. 345 K/PDT/2009, hlm. 13.

${ }^{86}$ Indonesia (2), Op.Cit., Pasal 31 ayat (1).

${ }^{87}$ Ibid., Pasal 33.

${ }^{88}$ Ibid., Pasal 115 ayat (1).
} 
paling terdampak oleh kepailitan adalah petitum yang menuntut korporasi melakukan "tindakan tertentu" dalam hal ini tindakan pemulihan. ${ }^{89}$ Berpindahnya kewenangan pengurusan harta pailit kepada kurator menghilangkan kewenangan debitur untuk menggunakan harta pailit guna melaksanakan kewajiban pemulihannya. Artinya, hukuman "tindakan tertentu" yang menjadi kewajiban debitur berpotensi tidak terlaksana karena keterbatasan perbuatan hukum korporasi terhadap hartanya.

\section{Terhadap Penegakan Hukum Ling- kungan Perdata di Luar Pengadilan}

Jika penegakan hukum lingkungan perdata di luar pengadilan disepakati sebelum korporasi dinyatakan pailit, maka ganti rugi atau biaya pemulihan dapat didaftarkan kepada kurator untuk dicocokkan. Hal ini disebabkan oleh pembayaran ganti rugi atau biaya pemulihan dapat dikualifikasi sebagai utang berdasarkan UU KPKPU. ${ }^{90}$ Eksekusi setelah didaftarkan ini akan dipengaruhi oleh posisi pemerintah sebagai kreditur.

Apabila proses penyelesaian di luar pengadilan belum selesai hingga korporasi dinyatakan pailit, maka kesepakatan tersebut tidak dapat dilaksanakan. Hal ini dikarenakan seluruh perikatan setelah korporasi dinyatakan pailit tidak dapat lagi dibayar dari harta pailit, kecuali menguntungkan harta pailit. ${ }^{91}$ Selain itu, tindakan pemulihan atau tindakan lainnya yang menyangkut harta pailit sulit untuk dilaksanakan sebab seluruh harta korporasi diurus oleh kurator. ${ }^{92}$ Eksekusi kesepakatan ini harus dilakukan sebelum putusan pengadilan.

Apabila penyelesaian luar pengadilan ini telah disepakati sebelum putusan pernyataan pailit, kesepakatan yang bukan berupa ganti rugi, seperti tindakan pemulihan sulit dilaksanakan. Perpindahan kewenangan mengurus harta korporasi kepada kurator ${ }^{93}$ menyebabkan debitur pailit kesulitan untuk melaksanakan kewajiban tindakan tersebut.

\section{B. Terhadap Penegakan Hukum Lingkungan Pidana}

UU KPKPU tidak mengatur akibat kepailitan terhadap perkara pidana yang sedang berlangsung, termasuk penyidikan. Sebaliknya, penegakan pidana terhadap korporasi dapat mempengaruhi kepailitan. Ketua Pengadilan Negeri dapat mengeluarkan penetapan yang menunda segala upaya atau proses kepailitan hingga adanya putusan pidana yang ber-

\footnotetext{
${ }^{89}$ Mahkamah Agung Republik Indonesia, Putusan No. 3067 K/PDT/2018, hlm. 32.

${ }^{90}$ Indonesia (2), Op.Cit., Pasal 1 angka 6.

${ }^{91}$ Ibid., Pasal 25.

92 Ibid., Pasal 24 ayat (1).

${ }^{93}$ Ibid., Pasal 24 ayat (1).
} 
kekuatan hukum tetap. Namun, penetapan tersebut hanya dapat dikeluarkan jika: (i) terdapat kekhawatiran korporasi membubarkan diri dengan tujuan menghindari pertanggungjawaban pidana; (ii) diminta oleh penyidik atau penuntut umum; (iii) hanya dapat diberikan sebelum permohonan pailit didaftarkan. ${ }^{94}$

Korporasi tetap dapat dimintakan pertanggungjawaban pidana selama proses kepailitan berlangsung. ${ }^{95}$ Namun, Peraturan MA Nomor 13 Tahun 2016 tentang Tata Cara Penanganan Tindak Pidana oleh Korporasi (Perma No. 13 Tahun 2016) mengatur bahwa korporasi yang telah bubar tidak dapat dipidana sehingga penuntutannya terbatas pada perampasan aset yang diduga digunakan untuk kejahatan atau hasil kejahatan. ${ }^{96}$ Waktu penjatuhan putusan hukum pidana yang berkekuatan hukum tetap tidak sepenuhnya dipengaruhi oleh putusan pernyataan pailit sepanjang korporasi belum bubar.

Apabila korporasi pailit telah bubar karena dinyatakan insolven dalam kepailitan atau pencabutan putusan per- nyataan pailit dan harta pailit perseroan tidak cukup untuk membayar biaya kepailitan $^{97}$, jaksa masih dapat menempuh jalur hukum melalui mekanisme gugatan. Namun, pelaksanaannya hanya dapat dilakukan jika: (i) dilakukan melalui gugatan di pengadilan umum; (ii) aset tersebut dikuasai oleh mantan pengurus, ahli waris, atau pihak ketiga; (iii) terbatas pada keuntungan korporasi yang digunakan untuk kejahatan atau diperoleh dari hasil kejahatan. ${ }^{98}$ Dengan demikian, meski korporasi dibubarkan melalui proses kepailitan, jaksa tetap dapat mengajukan gugatan perdata dengan syarat yang dijelaskan sebelumnya.

Terdapat dua jenis sanksi pidana yang memengaruhi aset korporasi, yakni pidana denda sebagai pidana pokok yang diatur dalam seluruh ketentuan UU PPLH ${ }^{99}$ dan pidana perampasan baik terhadap keuntungan yang diperoleh dari tindak pidana sebagai pidana tambahan ${ }^{100}$ maupun yang digunakan untuk melakukan tindak pidana untuk dilelang atau dihancurkan. ${ }^{101}$ Terhadap sanksi pidana denda, kepailitan akan mengubah

\footnotetext{
${ }^{94}$ Indonesia (11), Mahkamah Agung, Peraturan Mahkamah Agung tentang Tata Cara Penanganan Tindak Pidana oleh Korporasi, Perma No. 13 Tahun 2016, BN No. 2058 Tahun 2016, Pasal 16 ayat (1) dan (2).

${ }^{95}$ Ibid., Pasal 7 ayat (3).

${ }^{96}$ Ibid., Pasal 8 ayat (1).

${ }^{97}$ Indonesia (12), Undang-Undang Perseroan Terbatas, UU No. 40 Tahun 2007. LN No. 106 Tahun 2007, TLN No. 4756, Ps. 142 ayat (1) huruf e.

${ }^{98}$ Indonesia (11), Op.Cit., Pasal 8 ayat (1) dan (2).

${ }^{99}$ Indonesia (1), Op.Cit., Bab XV.

${ }^{100}$ Ibid., Pasal 119 huruf a.

${ }^{101}$ Indonesia (13), Undang-Undang tentang Hukum Acara Pidana, UU No. 8 Tahun 1981, LN No. 76
} 
Akibat Kepailitan pada Penegakan Hukum Lingkungan yang Berorientasi Pemulihan oleh Pemerintah dan/atau Pemerintah Daerah

denda menjadi utang. Hak yang timbul dari putusan pengadilan pidana dikualifikasi sebagai utang karena memenuhi Pasal 1 angka 6 UU KPKPU. ${ }^{102}$ Atas dasar tersebut, pidana denda yang dijatuhkan dianggap sebagai piutang dan didaftarkan kepada kurator. Sebagai tagihan yang didaftarkan, pidana denda tunduk pada seluruh ketentuan hukum kepailitan. Eksekusi setelah didaftarkan, dipengaruhi oleh posisi Pemerintah sebagai kreditur.

Selain menjadi utang, Perma No. 13 Tahun 2016 menentukan bahwa pidana denda yang tidak kunjung dibayar dapat dilaksanakan langsung oleh jaksa melalui penyitaan aset milik korporasi yang pailit untuk dilelang. ${ }^{103}$ Tidak ada ketentuan yang mengatur kriteria aset korporasi yang dapat disita untuk membayar pidana denda. ${ }^{104}$ Artinya, sepanjang aset tersebut masih menjadi milik korporasi, maka ia dapat disita untuk dilelang guna memenuhi pidana denda yang dikenakan.
Sehubungan dengan adanya kemungkinan sanksi denda berubah menjadi penyitaan, Pasal 31 ayat (2) UU KPKPU menyatakan bahwa semua penyitaan yang telah dilakukan menjadi hapus. Meski demikian, masih terdapat perdebatan mengenai hubungan sita pidana dan sita umum kepailitan. Freddy Haris, Mantan Sekretaris Direktorat Jenderal Administrasi Hukum Umum Kementerian Hukum dan HAM, berpendapat bahwa Pasal 201 HIR dan 463 Rv melarang sita rangkap sehingga setelah terjadi sita umum kepailitan, maka sita pidana tidak dapat dilakukan. ${ }^{105}$ Di sisi lain, Pasal 39 ayat (2) Undang-undang No. 8 Tahun 1981 tentang Hukum Acara Pidana menentukan bahwa benda-benda dalam sitaan pailit juga dapat dikenakan sita pidana untuk kepentingan penyidikan, penuntutan dan mengadili perkara pidana. Dualisme sita pidana dan sita umum kepailitan tersebut menimbulkan permasalahan dan ketidakpastian hukum dalam penerapannya. ${ }^{106}$

\footnotetext{
Tahun 1981, TLN No. 3258, Pasal 39 ayat (1), Pasal 46 ayat (2), Pasal 194 ayat (1).

${ }^{102}$ Indonesia (11), Op.Cit., Pasal 28 ayat (3).

${ }^{103}$ Ibid.

${ }^{104}$ Indonesia (14), Kejaksaan Republik Indonesia, Peraturan Kejaksaan Perubahan Kedua atas Peraturan Jaksa Agung Nomor PER-027/a/JA/10/2014 tentang Pedoman Pemulihan Aset, Peraturan Kejaksaan No. 7 Tahun 2020, Lampiran.

${ }^{105}$ Hukum Online, "Pro Kontra Sita Pidana vs Sita Umum Pailit", 2013, https://www.hukumonline.com/berita/baca/lt51836ecd9bbf8/prokontra-sita-pidana-vs-sita-umumpailit/, diakses pada 8 Agustus 2020.

${ }^{106}$ Dualisme sita pidana dan sita umum kepailitan tersebut sudah menjadi poin dari perubahan UU KPKPU yang dimuat naskah akademik. Badan Pembinaan Hukum Nasional, Naskah Akademik Rancangan Undang-Undang tentang Perubahan atas Undang-Undang Republik Indonesia Nomor 37 Tahun 2004 tentang Kepailitan dan Penundaan Kewajiban Pembayaran Utang, (Jakarta: Kementerian Hukum dan Hak Asasi Manusia, 2018), hlm. 117.
} 
Kepailitan sendiri tidak menghilangkan kepemilikan korporasi terhadap harta pailit, melainkan hanya menghilangkan hak korporasi untuk mengurus harta pailit tersebut. ${ }^{107}$ Namun dalam praktiknya, harta pailit dipisahkan dari harta yang dimiliki debitur sehingga tidak lagi dapat dieksekusi melalui mekanisme pidana karena harta yang masuk ke dalam harta pailit tidak lagi menjadi milik debitur. ${ }^{108}$ Dengan demikian, penegakan melalui perampasan aset ini belum terlalu jelas karena tidak ada ketentuan dalam UU KPKPU yang mengatur perampasan aset korporasi untuk melaksanakan putusan pengadilan pidana.

Pelaksanaan pidana denda maupun pidana perampasan tidak dinyatakan dalam suatu penetapan pengadilan. Pidana denda dan perampasan yang dinyatakan dalam putusan pengadilan dapat dilaksanakan oleh jaksa sepanjang telah berkekuatan hukum tetap ${ }^{109}$, sedangkan pidana perampasan yang berasal dari tidak dibayarkannya denda akan dapat dilaksanakan langsung oleh jaksa. ${ }^{110}$ Oleh karena putusan pailit hanya menghentikan eksekusi putusan yang dinyatakan dalam penetapan pelaksanaan pengadilan, maka pelaksanaan penegakan hukum pidana tidak terdampak oleh putusan pailit. ${ }^{111}$

Pidana tambahan perbaikan akibat tindak pidana berpotensi tidak terpenuhi karena hilangnya kewenangan korporasi untuk melakukan pengurusan dari harta pailit. Sebab, dengan berpindahnya kewenangan atas harta korporasi kepada kurator, membuat pelaksanaan jenis sanksi ini sulit. ${ }^{112}$

Berdasarkan uraian di atas, meski penegakan hukum pidana masih dapat dilakukan, terdapat berbagai hal yang belum diatur dengan jelas dalam UU KPKPU maupun hukum acara pidana. Hal-hal tersebut disebabkan oleh belum adanya sinkronisasi hukum kepailitan dengan penegakan hukum pidana secara keseluruhan.

\section{Terhadap Penegakan Hukum Lingkungan Administrasi}

Penegakan sanksi administratif dapat langsung dilakukan tanpa melalui proses

${ }^{107}$ Hubungan harta pailit dan korporasi diatur dalam Indonesia (2), Op.Cit, Pasal 24 ayat (1).

${ }^{108}$ Mahkamah Agung Republik Indonesia, Putusan No. 3 K/Pdt.Sus-Pailit/2019.

109 Indonesia (13), Op.Cit., Pasal 270: "Pelaksanaan putusan pengadilan yang telah memperoleh kekuatan hukum tetap dilakukan oleh jaksa, yang untuk itu panitera mengirimkan salinan surat putusan kepadanya." Pasal ini memberikan jaksa kewenangan untuk langsung mengeksekusi putusan pengadilan yang telah berkekuatan hukum tetap setelah putusan tersebut dikirimkan kepadanya.

${ }^{110}$ Indonesia (11), Op.Cit., Pasal 28 ayat (3).

${ }^{111}$ Indonesia (2), Op.Cit., Pasal 31 ayat (1).

112 Selain karena adanya kepailitan, kekosongan hukum yang mengatur tindak lanjut dari pidana tambahan yang dilalaikan oleh korporasi juga menjadi faktor tidak terlaksananya pidana tambahan perbaikan akibat tindak pidana. 
Akibat Kepailitan pada Penegakan Hukum Lingkungan yang Berorientasi Pemulihan oleh Pemerintah dan/atau Pemerintah Daerah

pengadilan. ${ }^{113}$ Pejabat administrasi dapat langsung menjatuhkan denda keterlambatan kepada pelaku usaha yang tidak melaksanakan paksaan pemerintah. ${ }^{114} \mathrm{Di}$ samping itu, tidak ada pengaturan yang membatasi tindakan hukum administrasi pemerintah terhadap korporasi pailit. Dalam hal korporasi dinyatakan pailit, proses penjatuhan sanksi administratif tidak akan terpengaruh seperti gugatan perdata. Ketentuan Pasal 31 ayat (1) UU KPKPU hanya menghentikan eksekusi yang didasarkan penetapan pengadilan-atau dengan kata lain adalah eksekusi dalam konteks perdata. ${ }^{115}$

Apabila korporasi telah dinyatakan pailit, maka Pemerintah sebagai kreditur dapat mengajukan pendaftaran tagihan atas denda keterlambatan kepada kurator untuk dicocokkan. ${ }^{116}$ Sanksi denda keterlambatan dapat diajukan dalam mekanisme kepailitan. Sanksi administrasi denda keterlambatan dapat dikualifikasi sebagai utang. ${ }^{117}$

\footnotetext{
${ }^{113}$ Wibisana (2), Op.Cit., hlm. 49.

${ }^{114}$ Indonesia (7), Op.Cit., Lampiran.

${ }^{115}$ Indonesia (2), Op.Cit., Pasal 31 ayat (1).

${ }^{116}$ Ibid., Pasal 27.

${ }^{117}$ Ibid., Pasal 1 angka 6.

${ }^{118}$ Ibid., Pasal 24 ayat (1).

${ }^{119}$ Indonesia (7), Op.Cit., Pasal 4 ayat (4) dan (5).

${ }^{120}$ Indonesia (1), Op.Cit., Pasal 109. “Setiap orang yang melakukan usaha dan/atau kegiatan tanpa memiliki izin lingkungan sebagaimana dimaksud dalam Pasal 36 ayat (1)" dikenakan sanksi pidana.

${ }^{121}$ Perdebatan apakah pencabutan izin lingkungan secara otomatis mencabut izin usaha dan/atau kegiatan dapat dilihat dalam Andri Gunawan Wibisana (3), "Pengelolaan Lingkungan melalui Izin Terintegrasi dan Berantai: Sebuah Perbandingan atas Perizinan Lingkungan di Berbagai Negara," Jurnal Hukum dan Pembangunan Vol. 48, No. 2 (2018), hlm. 248-249.
}

${ }^{122}$ Indonesia (2), Op.Cit., Pasal 104. 
diangkat juga terdorong untuk melakukan pembayaran denda keterlambatan atau paksaan pemerintah tertentu. Hal ini juga yang memberikan piutang yang timbul dari sanksi administrasi - termasuk denda keterlambatan-posisi yang lebih menguntungkan jika debitur masih hendak "menyelamatkan" korporasinya sebagai going concern.

Eksekusi sanksi tanpa melalui pendaftaran tagihan-yang dimungkinkan dalam kondisi "korporasi masih dapat diselamatkan" ini-dapat mempermudah eksekusi sanksi administrasi. Hal ini dapat berdampak pada pemulihan lingkungan yang lebih optimal. Kepailitan memakan waktu yang cukup lama dan membuka peluang tidak dilaksanakannya sanksi secara keseluruhan-karena pemenuhan kewajibannya bergantung pada kedudukan Pemerintah sebagai kreditur

\section{Kedudukan Pemerintah sebagai Kreditur dari Korporasi Pailit}

Penegakan hukum lingkungan secara perdata, pidana, maupun adminis- trasi dapat dilakukan meski korporasi jatuh pailit melalui pendaftaran tagihan kepada kurator. Namun, tidak terdapat ketentuan yang mengatur secara khusus apakah tagihan yang berasal dari penegakan hukum lingkungan akan memperoleh hak untuk didahulukan. Jika merujuk pada Pasal 1137 KUHPerdata, pembayaran ke kas negara memperoleh hak untuk didahulukan. ${ }^{123}$ Namun, agar dapat didahulukan, tagihan negara harus diatur dalam undang-undang secara khusus. ${ }^{124}$ Artinya, meski pembayaran hukuman terhadap korporasi dari instrumen perdata, pidana, dan administrasi masuk dalam kas negara dalam bentuk PNBP ${ }^{125}$, Pemerintah tidak serta-merta menjadi kreditur preferen karena Undang-undang No. 9 Tahun 2018 tentang PNBP tidak mengatur khusus hak didahulukan tersebut. ${ }^{126}$ Bandingkan misalnya dengan tagihan pajak yang memperoleh pengaturan secara khusus dalam Undang-undang tentang Ketentuan Umum Perpajakan. ${ }^{127}$ Namun dalam penerapannya, PNBP dapat dikualifikasi

${ }^{123}$ Mahkamah Konstitusi Republik Indonesia, Putusan Nomor 67/PUU-XI/2013, mengenai urutan prioritas pelunasan utang dalam kepailitan.

${ }^{124}$ R. Soebekti dan R. Tjitro Sudibyo, Burgerlijk Wetboek voor Indonesie, (Jakarta: Balai Pustaka, 2014), Pasal 1137.

${ }^{125}$ Penegakan hukum perdata dan administrasi adalah yang dilakukan oleh Kementerian Lingkungan Hidup dan tidak termasuk Pemerintah Daerah, Indonesia (4), Op. cit., Pasal 1 ayat (1) huruf k dan 1. Penegakan hukum pidana dilakukan oleh Jaksa, Indonesia (6), Op. cit., Ps. 1 ayat (1).

${ }^{126}$ Indonesia (15), Undang-undang Penerimaan Negara Bukan Pajak, UU No. 9 Tahun 2018, LN No. 147 Tahun 2018, TLN No. 6245.

${ }^{127}$ Indonesia (16), Undang-undang Ketentuan Umum Perpajakan, UU No. 6 Tahun 1983, LN No. 49 Tahun 1983, TLN Tahun 1983 No. 3262, Pasal 21 ayat (3a), yang mengatur:

"Dalam hal Wajib Pajak dinyatakan pailit, bubar, atau dilikuidasi maka kurator, likuidator, atau orang atau 
Akibat Kepailitan pada Penegakan Hukum Lingkungan yang Berorientasi Pemulihan oleh Pemerintah dan/atau Pemerintah Daerah

sebagai tagihan yang didahulukan maupun tidak. ${ }^{128}$ Selain ketidakjelasan kualifikasi tagihan tersebut, kedudukan Pemerintah baik sebagai kreditur preferen ataupun kreditur konkuren masih memiliki kekurangan masing-masing.

Dalam hukum kepailitan saat ini, kreditur preferen mempunyai posisi yang relatif tidak diuntungkan. Kreditur preferen tidak mempunyai hak suara untuk menyetujui atau menolak rencana perdamaian. ${ }^{129}$ Selain itu, hingga saat ini belum terdapat ketentuan yang mengatur tata cara pembayaran tagihan kepada kreditur preferen. Kemudian, tidak terdapat ketentuan yang mewajibkan agar rencana perdamaian memprioritaskan pembayaran kepada kreditur preferen. Hal ini mempersulit penegakan hukum lingkungan, khususnya terkait dengan sanksi denda keterlambatan yang angkanya dapat terus bertambah jika korporasi tidak melaksanakan paksaan pemerintah.
Tidak terdapat pula ketentuan yang mewajibkan agar rencana perdamaian memprioritaskan pembayaran kepada kreditur preferen. Kondisi demikian akan menghambat penegakan hukum lingkungan karena tidak memberikan kepastian pembayaran-meski secara hukum memperoleh prioritas untuk didahulukan.

Jika Pemerintah menjadi kreditur konkuren maka Pemerintah akan mempunyai hak suara untuk menyetujui atau menolak rencana perdamaian. ${ }^{130}$ Dalam rencana perdamaian tersebut, Pemerintah dapat menyepakati ulang ketentuan pembayaran dengan korporasi. Apabila rencana perdamaian ditolak dan kurator memulai pemberesan, maka Pemerintah berpotensi tidak mendapatkan pembayaran penuh. Hal ini disebabkan terdapat kemungkinan harta pailit berkurang dari eksekusi jaminan oleh kreditur separatis ${ }^{131}$ atau pembayaran kepada kreditur preferen. Pembayaran kepada kreditur

badan yang ditugasi untuk melakukan pemberesan dilarang membagikan harta Wajib Pajak dalam pailit, pembubaran atau likuidasi kepada pemegang saham atau kreditur lainnya sebelum menggunakan harta tersebut untuk membayar utang pajak Wajib Pajak tersebut"

${ }^{128}$ Shabrina Aliya Pramudita, Kartikasari, dan Amelia Cahyadini, "Kedudukan Hukum Menkominfo dalam Pelaksanaan Perdamaian Menurut Undang-Undang No. 37 Tahun 2004 tentang Kepailitan dan Penundaan Kewajiban Pembayaran Utang", Legal Standing, Vol. 4, No. 1, (Maret 2020), hlm. 104.

${ }^{129}$ Indonesia (2), Op.Cit., Pasal 151.

${ }^{130}$ Indonesia (2), Op.Cit.

${ }^{131}$ Kreditur separatis dapat melakukan eksekusi terhadap harta pailit yang dijaminkan padanya seolah-olah tidak terjadi kepailitan, Ibid., Pasal 55 ayat (1) yang mengatur:

"Dengan tetap memperhatikan ketentuan sebagaimana dimaksud dalam Pasal 56, Pasal 57, dan Pasal 58, setiap Kreditor pemegang gadai, jaminan fidusia, hak tanggungan, hipotek, atau hak agunan atas kebendaan lainnya, dapat mengeksekusi haknya seolah-olah tidak terjadi kepailitan." 
konkuren akan dilakukan berdasarkan secara proporsional, atau disebut juga sebagai pari passu, yaitu menurut perbandingan besarnya masing-masing tagihan mereka. ${ }^{132}$ Oleh karena itu, eksekusi sanksi dapat terlaksana lebih baik apabila rencana perdamaian ini disetujui oleh kurator. Pembayaran tidak penuh dapat menghambat tercapainya tujuan pemulihan, khususnya terhadap jenis sanksi yang komponen pembiayaannya telah ditentukan secara spesifik, seperti biaya pemulihan. Pembayaran yang tidak penuh ini dapat menghilangkan beberapa komponen pemulihan.

Terlepas dari kedudukannya sebagai kreditur dalam proses kepailitan, opsi terbaik bagi Pemerintah adalah agar pelaksanaan dari penegakan hukum lingkungan dapat diselesaikan sebelum korporasi jatuh pailit. Pemerintah memperoleh perlindungan dari gugatan-gugatan actio pauliana $a^{133}$ untuk pembayaran dalam rangka melaksanakan sanksi dari berbagai instrumen. Meskipun hukum perdata dan kepailitan mengakui gugatan actio pauliana untuk melindungi kreditur ${ }^{134}$, pembayaran berbagai sanksi merupakan pengecualian. Pembayaran sanksi merupakan bentuk perbuatan hukum yang dilakukan karena undang-undang sehingga dikecualikan dari gugatan action pauliana. Dengan adanya pengecualian dari actio pauliana, pembayaran sanksi sebelum korporasi pailit terlindungi dari pembatalan.

\section{Penutup}

Pada dasarnya, pelaksanaan sanksi yang dapat dilakukan melalui mekanisme kepailitan hanyalah yang dapat dinilai dengan uang, seperti denda pidana, ganti rugi atau biaya pemulihan, ataupun denda keterlambatan. Untuk sanksi lainnya yang berkaitan dengan pemulihan seperti perbaikan akibat tindak pidana, tindakan tertentu, ataupun paksaan pemerintah sulit dilakukan karena setelah dinyatakan pailit, seluruh harta korporasi diurus oleh kurator.

Ketiga instrumen penegakan hukum lingkungan dapat didaftarkan sebagai tagihan kepada kurator. Namun, belum ada kejelasan apakah Pemerintah akan menjadi kreditur preferen atau konkuren. Hal ini disebabkan seluruh jenis sanksi dalam ketiga instrumen---yang dinyatakan sebagai PNPB - belum diatur secara jelas dalam undang-undang khusus untuk dahulukan sehingga memenuhi kualifikasi Pasal 1137 KUHPerdata. Selain itu, eksekusi sanksi oleh Pemerintah terhadap kedua jenis kedudukan kreditur tersebut memiliki kekurangannya masing-masing.

\footnotetext{
${ }^{132}$ Soebekti dan Tjitro Sudibyo, Op.Cit., Pasal 1132.

${ }^{133}$ Ibid., Pasal 1341 dan Indonesia (2), Op.Cit., Pasal 41.

${ }^{134}$ Indonesia (2), Op.Cit.
} 
Akibat Kepailitan pada Penegakan Hukum Lingkungan yang Berorientasi Pemulihan oleh Pemerintah dan/atau Pemerintah Daerah

Meski secara umum ketiganya dapat didaftarkan kepada kurator, kepailitan juga memiliki dampak yang berbeda terhadap ketiga instrumen tersebut. Dalam penegakan hukum perdata, gugatan Pemerintah dinyatakan gugur apabila belum diputuskan melalui putusan berkekuatan hukum tetap sebelum putusan pernyataan pailit. Dalam penegakan pidana, keadaan pailit masih menyisakan pertanyaan mengenai kedudukan sita pidana terhadap sita umum kepailitan dan juga dimungkinkannya perampasan aset korporasi yang masuk dalam harta pailit. Penegakan hukum pidana juga memperoleh pengaturan khusus dan dapat dilakukan terhadap pihak ketiga meski korporasi dibubarkan. Hal ini berbeda dengan proses penegakan administrasi yang tidak terpengaruh oleh kepailitan. Bahkan, denda keterlambatan dapat dibayarkan oleh kurator jika dianggap perlu untuk melanjutkan usaha debitur pailit.
Skenario terbaik bagi Pemerintah adalah ketika korporasi secara sukarela membayar sanksi yang dikenakan sebelum dinyatakan pailit. Hal ini disebabkan pembayaran sanksi tidak memenuhi kualifikasi perbuatan hukum yang dapat diajukan actio pauliana sehingga tidak dapat dibatalkan. Meskipun demikian, pelaksanaan ini bergantung pada iktikad korporasi.

Kepailitan dapat menghambat proses penjatuhan ataupun eksekusi sanksi, termasuk sanksi yang berkaitan dengan pemulihan. Kepailitan memiliki dampak yang berbeda untuk setiap instrumen. Sanksi pemulihan lingkungan hanya dapat dilaksanakan dalam beberapa kondisi tertentu saja, Pemerintah perlu mempertimbangkan perbedaan dampak dan kondisi tertentu tersebut dalam penggunaan instrumen penegakan hukum lingkungan yang berorientasi pada pemulihan. 


\section{DAFTAR PUSTAKA}

\section{Peraturan Perundang-Undangan}

Indonesia. Undang-Undang Dasar 1945.

Undang-undang Hukum Acara Pidana, UU No. 8 Tahun 1981, LN No. 76 Tahun 1981, TLN No. 3258.

Undang-undang Ketentuan Umum Perpajakan, UU No. 6 Tahun 1983, LN No. 49 Tahun 1983, TLN Tahun 1983 No. 3262.

Undang-Undang Kepailitan Dan

Penundaan Kewajiban Pembayaran Utang, UU No. 37 Tahun 2004, LN No. 131 Tahun 2004, TLN No. 4443.

Undang-Undang Perseroan Terbatas, UU No. 40 Tahun 2007. LN No. 106 Tahun 2007, TLN No. 4756

, Undang-Undang Perlindungan dan Pengelolaan Lingkungan Hidup, UU No. 32 Tahun 2009, LN No. 140 Tahun 2009, TLN No. 5059.

Undang-Undang Penerimaan Negara Bukan Pajak, UU No. 9 Tahun 2018, LN No. 147 Tahun 2018, TLN No. 6245.

Pemerintah Indonesia, Peraturan Pemerintah tentang Jenis dan Tarif atas Jenis Penerimaan Negara Bukan Pajak yang Berlaku pada Kementerian Lingkungan Hidup, PP No. 44 Tahun 2014, LN No. 124 Tahun 2014, TLN No. 5540.

Pemerintah Indonesia, Peraturan Pemerintah tentang Jenis dan Tarif Atas Jenis Penerimaan Negara Bukan Pajak Yang Berlaku Pada Kejaksaan Republik
Indonesia, PP No. 39 Tahun 2016, LN No. 199 Tahun 2016, TLN No. 5935,

Pemerintah Indonesia, Peraturan Pemerintah tentang Pengelolaan Keuangan Daerah, PP No. 12 Tahun 2019, LN No. 42 Tahun 2019, TLN No. 6322

Menteri Lingkungan Hidup, Peraturan Menteri Lingkungan Hidup Pedoman Penerapan Sanksi Administratif di Bidang Perlindungan dan Pengelolaan Lingkungan Hidup, Permen LH No. 2 Tahun 2013, BN No. 314 Tahun 2013,

Menteri Lingkungan Hidup, Peraturan Menteri tentang Kerugian Lingkungan Hidup Akibat Pencemaran dan/atau Kerusakan Lingkungan Hidup, Permen No. 7 Tahun 2014, BN No. 1726 Tahun 2014,

Kejaksaan Republik Indonesia, Peraturan Kejaksaan Perubahan Kedua atas Peraturan Jaksa Agung Nomor PER-027/a/JA/10/2014 tentang Pedoman Pemulihan Aset, Peraturan Kejaksaan No. 7 Tahun 2020.

Gubernur Sumatera Selatan, Peraturan Gubernur tentang Tata Cara Penerapan Sanksi Administratif di Bidang Perlindungan dan Pengelolaan Lingkungan Hidup, Pergub No. 12 Tahun 2019, BD No. 12 Tahun 2019.

Bupati Bangka Barat, Peraturan Bupati tentang Pedoman Penerapan Sanksi Administratif di Bidang Perlindungan dan Pengelolaan Lingkungan Hidup, Perbup No. 15 Tahun 2015, BD No. 2 Tahun 2015, 
Akibat Kepailitan pada Penegakan Hukum Lingkungan yang Berorientasi Pemulihan oleh Pemerintah dan/atau Pemerintah Daerah

Mahkamah Agung Republik Indonesia, "Peraturan Mahkamah Agung tentang Tata Cara Penanganan Tindak Pidana oleh Korporasi", PERMA No. 13 Tahun 2016, BN No. 2058 Tahun 2016.

\section{Putusan Pengadilan}

Mahkamah Agung Republik Indonesia, Putusan No. 345 K/PDT/2009. , Putusan 2042 K/Pdt.Sus/2015. , Putusan No. 1423 K/Pdt/ 2017. , Putusan No. 3067 K/PDT/2018 lit/2019.

Pengadilan Negeri Jakarta Selatan, Putusan No. 591/Pdt.G-LH/2015/ PN.Jkt. Sel.

Pengadilan Negeri Makassar, Putusan No. 89/Pdt.G/2015/PN.Mks.

Pengadilan Negeri Malang, Putusan Nomor 139/Pdt.G/2013/PN.Mlg.

Pengadilan Negeri Tanjung Jabung Timur, Putusan Nomor 40/Pid.Sus-LH/2019/PN Tjt

Pengadilan Niaga pada Pengadilan Negeri Jakarta Pusat, Putusan No. 09/ Pdt.Sus/Pembatalan Perdamaian/2016/PN.NIAGA.JKT.PST

Pengadilan Niaga pada Pengadilan Negeri Surabaya, Putusan No. 5/Pdt. Sus-PKPU/2014/PN.Niaga Sby,

Pengadilan Tata Usaha Negara Jakarta, Putusan No. 104/G/LH/2017/ PTUN-JKT

Pengadilan Tinggi DKI Jakarta, Putusan Nomor 296 /PDT/2020/PT.DKI, hlm. 171.
Pengadilan Tinggi Jambi, Putusan No. 65/PDT-LH/2017/PT JMB.

Pengadilan Tinggi Semarang, Putusan Nomor 272/PDT/2019/PT.Smg.

\section{Buku}

Fuady, Munir. Perbuatan Melawan Hukum Pendekatan Kontemporer. Jakarta: PT Citra Aditya Bakti, 2005.

Kansil, C.S.T. dan Christine S.T. Kansil. Pokok-pokok Hukum Pidana. Jakarta: Pradnya Paramita, 2004.

Moeljatno, Kitab Undang-Undang Hukum Pidana [Wetboek van Straftrecht], Jakarta: Pradnya Paramita, 1996.

Nating, Imran. Peranan Dan Tanggung Jawab Kurator Dalam Pengurusan Dan Pemberesan Kepailitan. Jakarta: Raja Grafindo Persada, 2005.

Setiady, Tolib Setiady. Pokok-Pokok Hukum Panitensier Indonesia. Bandung: Alfabeta, 2010.

Shubhan, M. Hadi. Hukum Kepailitan: Prinsip, Norma, dan Praktik di Peradilan. Jakarta: Kencana, 2009.

Sjahdeini, Sutan Remy. Hukum Kepailitan: Memahami Undang-undang No. $37 \mathrm{Ta}$ hun 2004 tentang Kepailitan. Jakarta: Pustaka Utama Grafiti, 2009.

Soebekti, R. dan R. Tjitro Sudibyo, Burgerlijk Wetboek voor Indonesie, Jakarta: Balai Pustaka, 2014.

Soesilo, R. Pokok-Pokok Hukum Pidana Peraturan Umum dan Delik-Delik Khusus, Cetakan ke-1. Sukabumi: PT. Karya Nusantara, 1984. 
Sofyan, Andi Sofyan dan Nur Azisa. Hukum Pidana. Makassar: Pustaka Pena Press, 2016.

Syarif, Laode M dan Andri G Wibisana, (ed.). Hukum Lingkungan Teori, Legislasi, dan Studi Kasus. s.l. USAID-Kemitraan Partnership-the Asia Foundation, 2015.

\section{Artikel Jurnal/Media Massa}

Harahap, Zairin. "Penegakan Hukum Lingkungan Menurut Hukum Lingkungan," Jurnal Hukum, Vol. 11, No. 27, September 2004.

Nurlinda, Ida. "Kebijakan Pengelolaan Sumber Daya Alam dan Dampaknya Terhadap Penegakan Hukum Lingkungan Indonesia," Bina Hukum Lingkungan, Vol. 1, No. 1, Oktober 2016.

Pramudita, Shabrina Aliya, Kartikasari, dan Amelia Cahyadini. "Kedudukan Hukum Menkominfo dalam Pelaksanaan Perdamaian Menurut Undang-Undang No. 37 Tahun 2004 tentang Kepailitan dan Penundaan Kewajiban Pembayaran Utang," Legal Standing, Vol. 4, No. 1, Maret 2020.

Susilo, Agus Budi. "Makna Perbuatan Hukum Publik oleh Badan atau Pejabat Administrasi Negara yang Melanggar (Suatu Tinjauan Yuridis Menurut Hukum Administrasi Negara)," Perspektif, Vol. 15, No. 4. Oktober 2010.

Syaprillah, Aditia. "Penegakan Hukum Administrasi Melalui Instrumen
Pengawasan," Bina Hukum Lingkungan, Vol. 1 No. 1, Oktober 2016.

Wibisana, Andri Gunawan. “Tangan Tuhan di Pengadilan: Dalih Bencana Alam dan Pertanggungjawaban Perdata dalam Kasus Lingkungan," Jurnal Hukum dan Pembangunan, Vol. 41, No. 1, Januari-Maret 2011.

"Tentang Ekor yang Tak Lagi Beracun: Kritik Konseptual atas Sanksi Administratif dalam Hukum Lingkungan di Indonesia," Jurnal Hukum Lingkungan Indonesia, Vol. 6, No. 1, 2019.

"Pengelolaan Lingkungan melalui Izin Terintegrasi dan Berantai: Sebuah Perbandingan atas Perizinan Lingkungan di Berbagai Negara," Jurnal Hukum dan Pembangunan, Vol. 48, No. 2, 2018.

\section{Lain-Lain}

Badan Pembinaan Hukum Nasional, Naskah Akademik Rancangan Undang-Undang tentang Perubahan atas Undang-Undang Republik Indonesia Nomor 37 Tahun 2004 tentang Kepailitan dan Penundaan Kewajiban Pembayaran Utang. Jakarta: Kementerian Hukum dan Hak Asasi Manusia, 2018.

Hukum Online, "Pro Kontra Sita Pidana vs Sita Umum Pailit", https://www. hukumonline.com/berita/baca/ 1t51836ecd 9bbf8/prokontra-sita-pidana-vs-sita-umumpailit/, diakses pada 8 Agustus 2020. 
Azam Hawari dan Deni Daniel

Akibat Kepailitan pada Penegakan Hukum Lingkungan yang Berorientasi Pemulihan oleh Pemerintah dan/atau Pemerintah Daerah

Pane, Marjan E., "Inventarisasi dan Verifikasi dalam Rangka Pemberesan Harta Pailit dalam Pelaksanaannya," Dalam Emmy Yuhassarie (ed.), Undang-undang Kepailitan dan Perkembangannya, Jakarta: Pusat Pengkajian Hukum, 2005.

United Nations General Assembly, Report of the United Nations Conference on Environment and Development, Rio de Janeiro, 3-14 Juni 1992. 